\title{
Mercury levels of yellowfin tuna (Thunnus albacares) are associated with capture location ${ }^{\text {is }}$
}

\author{
Sascha C.T. Nicklisch, Lindsay T. Bonito, Stuart Sandin, Amro Hamdoun* \\ Marine Biology Research Division, Scripps Institution of Oceanography, University of California San Diego, La Jolla, CA 92093-0202, United States
}

\section{A R T I C L E I N F O}

\section{Article history:}

Received 27 February 2017

Received in revised form

5 May 2017

Accepted 24 May 2017

\section{Keywords:}

Mercury

Yellowfin tuna

Capture location

Global assessment

Pollution

\begin{abstract}
A B S T R A C T
Mercury is a toxic compound to which humans are exposed by consumption of fish. Current fish consumption advisories focus on minimizing the risk posed by the species that are most likely to have high levels of mercury. Less accounted for is the variation within species, and the potential role of the geographic origin of a fish in determining its mercury level. Here we surveyed the mercury levels in 117 yellowfin tuna caught from 12 different locations worldwide. Our results indicated significant variation in yellowfin tuna methylmercury load, with levels that ranged from 0.03 to $0.82 \mu \mathrm{g} / \mathrm{g}$ wet weight across individual fish. Mean mercury levels were only weakly associated with fish size $\left(R^{2}<0.1461\right)$ or lipid content $\left(R^{2}<0.00007\right)$ but varied significantly, by a factor of 8 , between sites. The results indicate that the geographic origin of fish can govern mercury load, and argue for better traceability of fish to improve the accuracy of exposure risk predictions.
\end{abstract}

() 2017 Elsevier Ltd. All rights reserved.

\section{Introduction}

Mercury is a widespread environmental toxicant of concern for wildlife and human health. Mercury occurs naturally and is also released into the atmosphere through anthropogenic sources, most notably the combustion of coal (Driscoll et al., 2013; Fitzgerald and Lamborg, 2007; Gustin et al., 2008; Mason et al., 1994; Selin, 2009). Atmospheric mercury is deposited into the oceans, where it is converted into inorganic and/or organic mercury (Mason et al., 1994). The inorganic mercury exhibits limited bioaccumulation, while the organic form (methylmercury) is highly refractory and bioaccumulates in high trophic level animals (Mason et al., 1995; Morel et al., 1998).

Methylmercury is a neurotoxicant in humans and wildlife (BoseO'Reilly et al., 2010; Grandjean et al., 2010; Rice et al., 2014; Scheuhammer et al., 2007; Wiener and Spry, 1996), and is a reactive molecule that can bind to cellular proteins thereby increasing its half-life in the cell (Bošnjak et al., 2009; Mason et al., 1996). High levels of methylmercury in the human body have been associated with developmental disorders, including neurological effects

\footnotetext{
Abbreviations: Hg, mercury; $\mathrm{MeHg}$, methylmercury.

* This paper has been recommended for acceptance by Maria Cristina Fossi.

* Corresponding author.

E-mail address: hamdoun@ucsd.edu (A. Hamdoun).
}

(Antunes Dos Santos et al., 2016; Counter and Buchanan, 2004; Karagas et al., 2012). Importantly, it is estimated that in the United States alone each year at least 316,000 , and possibly as many as 637,000 , children are born with umbilical cord blood levels of mercury sufficient to cause neurodevelopmental defects (Trasande et al., 2005).

Consumption of contaminated seafood is considered the major route of human exposure to mercury (Castro-González and Méndez-Armenta, 2008; Kraepiel et al., 2003; Rice et al., 2014), and fish consumption advisories routinely recommend a reduction of intake of high mercury fish by pregnant and nursing women. In addition, considerable attention has been given to understanding the distribution of mercury in commercial food fish (Colman et al., 2015; Hightower and Moore, 2003; Lowenstein et al., 2010; Yamashita et al., 2005), as high levels of mercury have been reported in large predatory fish species including swordfish, sharks, and tuna (FDA, 2014; García-Hernández et al., 2007; Kaneko and Ralston, 2007; Matthews, 1983).

Among these species, tunas are of primary importance, as they are one of the most widely consumed group of fish species in the world. Three species of tunas, skipjack (Katsuwonus pelamis), yellowfin (Thunnus albacares), and bigeye (Thunnus obesus) account for $93 \%$ of all tuna consumed (ISSF, 2015). Among these, yellowfin and bigeye are large predatory fish with high levels of mercury (Boush and Thieleke, 1983; Kaneko and Ralston, 2007; Kojadinovic et al., 2006; Kraepiel et al., 2003; Ordiano-Flores et al., 2011), often 
Table 1

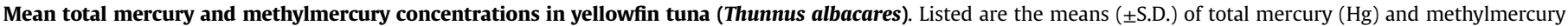

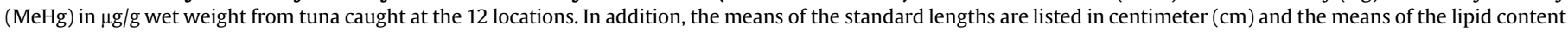

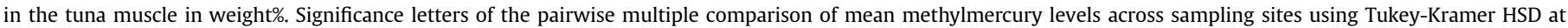
$\alpha=0.05$ are listed (A-D). For details on the p-values of the respective pairwise comparison, please refer to Table S1.

\begin{tabular}{|c|c|c|c|c|c|c|c|c|c|}
\hline Sampling sites & $\begin{array}{l}\text { Samples } \\
{[\mathrm{n}]}\end{array}$ & $\begin{array}{l}\text { Total Hg } \\
{[\mu \mathrm{g} / \mathrm{g} \mathrm{ww}]}\end{array}$ & $\begin{array}{l}\mathrm{MeHg} \\
{[\mu \mathrm{g} / \mathrm{g} \mathrm{ww}]}\end{array}$ & Letters & & & & $\begin{array}{l}\text { Standard length } \\
{[\mathrm{cm}]}\end{array}$ & $\begin{array}{l}\text { Lipids } \\
\text { [wt\%] }\end{array}$ \\
\hline NPO & 10 & $0.602 \pm 0.181$ & $0.506 \pm 0.166$ & A & & & & $117.35 \pm 19.06$ & $1.52 \pm 1.16$ \\
\hline NEPO & 10 & $0.154 \pm 0.026$ & $0.164 \pm 0.024$ & & & $\mathrm{C}$ & $\mathrm{D}$ & $55.87 \pm 1.97$ & $3.25 \pm 1.12$ \\
\hline GOM & 9 & $0.23 \pm 0.171$ & $0.246 \pm 0.176$ & & B & C & & $103.72 \pm 13.36$ & $1.23 \pm 1.04$ \\
\hline SEPO & 10 & $0.297 \pm 0.176$ & $0.238 \pm 0.133$ & & B & C & & $71.45 \pm 3.99$ & $1.23 \pm 0.85$ \\
\hline NWAO & 10 & $0.43 \pm 0.085$ & $0.345 \pm 0.077$ & & B & & & $92.8 \pm 3.49$ & $0.41 \pm 0.16$ \\
\hline NEAO & 10 & $0.206 \pm 0.035$ & $0.199 \pm 0.036$ & & B & $\mathrm{C}$ & $\mathrm{D}$ & $80.42 \pm 7.13$ & $6.08 \pm 2.56$ \\
\hline SEAO & 8 & $0.348 \pm 0.101$ & $0.308 \pm 0.088$ & & B & $\mathrm{C}$ & & $84.94 \pm 23.22$ & $2.76 \pm 1.38$ \\
\hline IO & 10 & $0.245 \pm 0.055$ & $0.236 \pm 0.057$ & & B & $\mathrm{C}$ & & $97.07 \pm 2.32^{\mathrm{a}}$ & $0.6 \pm 0.18$ \\
\hline SCS & 10 & $0.181 \pm 0.042$ & $0.16 \pm 0.035$ & & & $\mathrm{C}$ & $\mathrm{D}$ & $109.4 \pm 8.6$ & $1.09 \pm 0.58$ \\
\hline NCS & 10 & $0.269 \pm 0.027$ & $0.224 \pm 0.019$ & & B & $\mathrm{C}$ & & $96.9 \pm 3.67$ & $0.71 \pm 0.6$ \\
\hline NWPO & 10 & $0.064 \pm 0.016$ & $0.064 \pm 0.018$ & & & $\mathrm{D}$ & & $100.45 \pm 1.15$ & $0.68 \pm 0.2$ \\
\hline SWPO & 10 & $0.239 \pm 0.151$ & $0.234 \pm 0.149$ & & B & $\mathrm{C}$ & & $108.25 \pm 25.93$ & $0.62 \pm 0.45$ \\
\hline
\end{tabular}

a Fork length.

exceeding the EPA consumption advisory limit of $0.3 \mu \mathrm{g} / \mathrm{g}$ wet weight (USEPA, 2010). For instance, in raw (i.e. sushi) tuna preparations collected from restaurants and supermarkets in New York, New Jersey, and Colorado, bigeye tuna with mercury levels up to $2.3 \mu \mathrm{g} / \mathrm{g}$ wet weight were reported, while yellowfin samples had mercury levels as high as $1.4 \mu \mathrm{g} / \mathrm{g}$ wet weight (Lowenstein et al., 2010).

Numerous factors can contribute to variation in mercury levels within fish, generally including species, size, migratory biology, and origin. While several studies in tuna have examined associations between fish size and mercury levels (Bosch et al., 2016; Drevnick et al., 2015), less is known about the impact of capture location, with most studies focusing on regional versus global differences (Colman et al., 2015; Cumont et al., 1972; Ferriss et al., 2011; Hall et al., 1978; Kojadinovic et al., 2006). In one recent study, juveniles of the highly migratory bluefin tuna (Thunnus orientalis) showed elevated levels of mercury upon arrival in the eastern Pacific Ocean, possibly consistent with exposure occurring during their development in the western Pacific Ocean (Colman et al., 2015). Thus, further characterization of geographic variation is essential to better understand how fish origin can govern mercury level.

Yellowfin tuna are distributed worldwide in the tropical and subtropical waters and provide an interesting case study in which to examine differences in mercury levels from different locations. Yellowfin are the second most widely consumed tuna species in the world and account for $27 \%$ of the global catch (ISSF, 2015). Like other large predatory fish, yellowfin can magnify mercury through trophic transfer up the food web, but because they do not migrate across oceans (Block et al., 2011), would be expected to reflect geographic differences in mercury levels.

To explore this variability, we measured mercury levels in white dorsal muscle tissue of 117 yellowfins caught at 12 different locations from around the globe. The results indicate that capture location of fish could be a critical factor in determining the mercury level of yellowfin and argue for improved traceability of these fish in the global food supply.

\section{Material and methods}

\subsection{Tuna collection}

Mixed-sex yellowfin tuna (Thunnus albacares) were collected from across the globe from the four known yellowfin stocks in the Atlantic Ocean, the Eastern Pacific, the Western Pacific, and the
Indian Ocean (ISSF, 2015). Collectors were either from Scripps Institution of Oceanography (SIO) or affiliated with local academic and commercial fisheries. The white dorsal muscle tissue was sampled from 12 locations, including the North East Pacific Ocean (NEPO; $n=10$ ), Gulf of Mexico (GOM; $n=9$ ), South East Pacific Ocean (SEPO; $\mathrm{n}=10$ ), Northwest Atlantic (NWAO; $\mathrm{n}=10$ ), Northeast Atlantic Ocean (NEAO; $\mathrm{n}=10$ ), South East Atlantic Ocean (SEAO; $\mathrm{n}=8$ ), Indian Ocean (IO; $\mathrm{n}=10$ ), South China Sea (SCS; $\mathrm{n}=10$ ), North China Sea (NCS; $\mathrm{n}=10$ ), Northwest Pacific Ocean (NWPO; $n=10$ ), Southwest Pacific Ocean (SWPO; $n=10$ ), and the North Pacific Ocean (NPO; $n=10$ ). The target sampling size was $100 \mathrm{~cm}$, translating to roughly $1-2$ years old yellowfin (Kikkawa and Cushing, 2002). All tunas were either captured by trolling, purse seine or longline and coordinates for capture were recorded to within $100 \mathrm{~km}$. Captured tuna were filleted and the dorsal muscle immediately frozen on ice. Tuna muscle were stored at $-20^{\circ} \mathrm{C}$ until shipped on dry ice to SIO. At SIO, all samples were stored at $-80{ }^{\circ} \mathrm{C}$ at SIO, and subsamples of $56.7 \mathrm{~g} \mathrm{(2oz)}$ or $113.4 \mathrm{~g}$ (4oz) were sent on dry ice to Brooks Rand Labs (BRL, Seattle, WA) for analysis of total mercury $(\mathrm{Hg})$, methylmercury (MeHg).

\subsection{Mercury analysis}

All samples were received, prepared, analyzed, and stored per BRL standard operating procedures (SOPs) and Environmental Protection Agency (EPA) methodology. The method holding time requirement was met such that all samples were analyzed within one year from collection. Total mercury $(\mathrm{Hg})$ and methylmercury (MeHg) were measured per EPA methods $1631 \mathrm{E}$ and 1630. Briefly, for total mercury detection all mercury was oxidized to $\mathrm{Hg}$ (II), purged, and trapped using a BRL MERX-T unit, and finally detected using a Brooks Rand Model III cold vapor atomic fluorescence spectrophotometer (CVAFS). For methylmercury detection, samples were purged and trapped using a BRL MERX-M unit, the released $\mathrm{Hg}$ species separated using gas chromatography (GC), thermally reduced to elemental mercury, and finally detected using a Brooks Rand Model III cold vapor atomic fluorescence spectrophotometer (CVAFS).

\subsection{Data analysis}

All samples were reported on a wet-weight basis. For methylmercury, the certified reference material was TORT-2 and DOLT-4 dogfish liver certified for trace metals. For total mercury, the certified reference material was DORM-3 fish protein certified for 

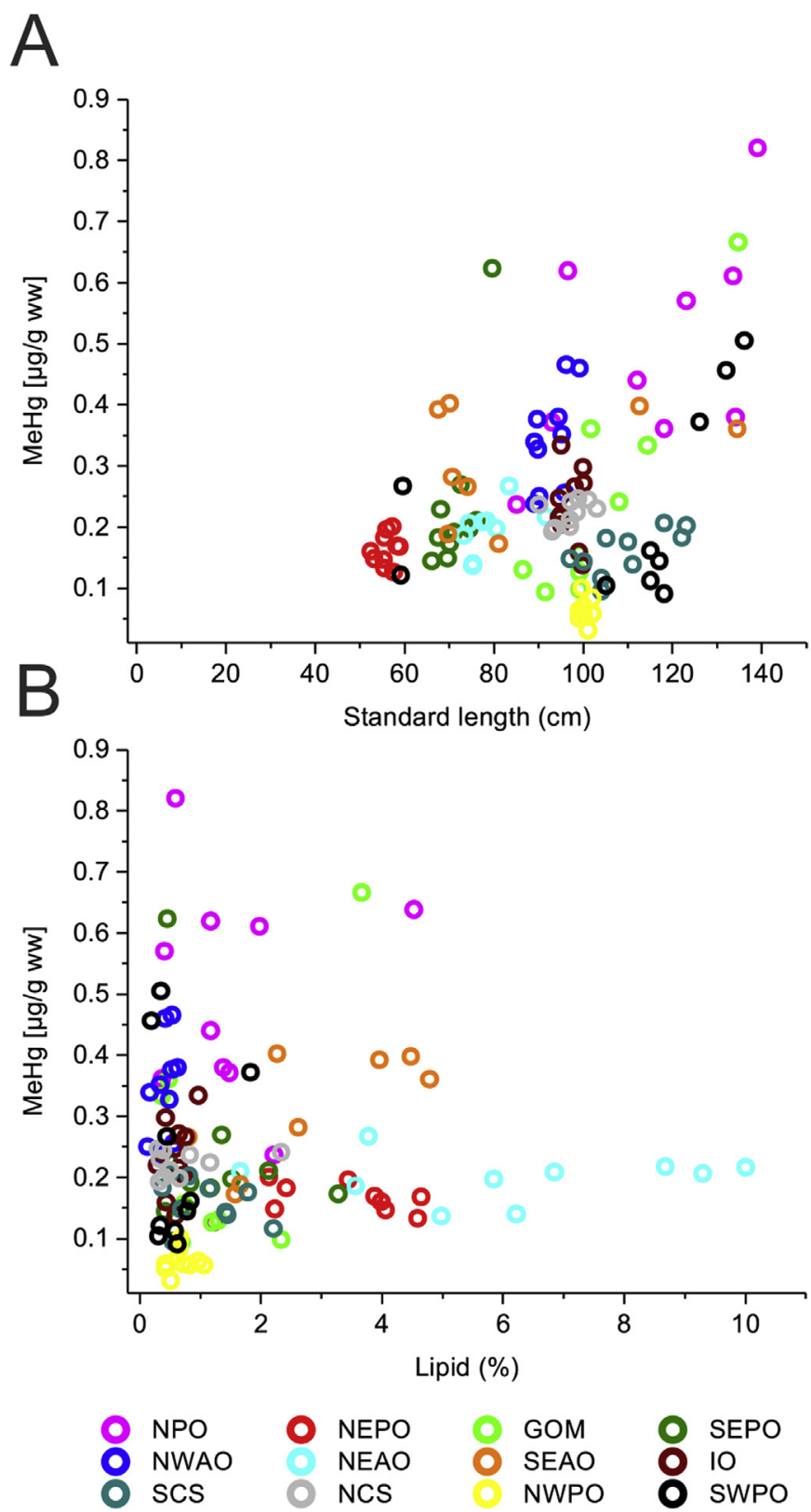

Fig. 1. Relationships between fish length and lipid content, versus methylmercury concentration. (A) Methylmercury concentration of each of the 117-individual fish versus standard length in $\mathrm{cm}\left(\mathrm{R}^{2}<0.1461\right.$, Pearson's $\left.\mathrm{r}<0.3822\right)$. The slope of the fitted regression line was significantly different from zero $(\mathrm{p}<0.0001)$. (B) Methylmercury concentration versus lipid content from 117 individual fish $\left(R^{2}<0.00007\right.$, Pearson's $r<-0.00837$ ). The slope of the fitted regression line was not significantly different from zero $(\mathrm{p}<0.9286)$.

trace metals. Duplicates and spike recovery were used to confirm reproducibility and accuracy of measurements. Method detection limits (MDLs) and method reporting limits (MRLs) were samplespecific and adjusted for the mass of sample aliquot digested and the volume of digestate analyzed. For total mercury, MDLs ranged from 0.54 to $4.82 \mathrm{ng} / \mathrm{g}$ and MRLs ranged from 1.8 to $16.1 \mathrm{ng} / \mathrm{g}$ wet weight. For methylmercury, MDLs ranged from 0.9 to $1.6 \mathrm{ng} / \mathrm{g}$ and MRLs ranged from 2.7 to $4.8 \mathrm{ng} / \mathrm{g}$ wet weight. The results of the analysis were method blank corrected per BRL standard operating procedure (SOP). For this, four method blanks were analyzed with every batch of samples and if the mean value and standard deviation of those blanks met the acceptance criteria (i.e. the mean was
$<2 \mathrm{ng} / \mathrm{g}$ wet weight and the standard deviation was $<0.7 \mathrm{ng} / \mathrm{g}$ wet weight), the mean of the method blank results was subtracted from the sample results. Consistent with previous studies, virtually all the mercury detected in tuna was in the form of methylmercury (Table 1).

To measure the correlation between methylmercury concentration and lipid content or length of the fish, we applied linear regression analysis and determined Pearson's correlation coefficient ( $\mathrm{r}$ ) and coefficient of determination (COD or $\mathrm{R}^{2}$ ). To test the differences among sampling locations, we used one-way analysis of variance (ANOVA) followed by a Tukey post-hoc test. The null hypothesis of equal means between locations was rejected when the p-value was below a significance level of $\alpha=0.05$. Detailed information on the ordered $\mathrm{p}$-values for each pairwise comparison of sample locations from the Tukey-Kramer honest significant difference (HSD) test are provided in Table S1. All data were analyzed and plotted using the programs JMP Pro version 12 and OriginPro 2016.

\section{Results and discussion}

Here we measured mercury concentrations in white dorsal muscle of yellowfin tuna caught from 12 different locations worldwide and investigated the role of size and regional differences in mercury level. We selected for white muscle tuna samples since this tissue type has been shown to have more conservative mercury levels with lower variability as compared to dark muscle (Balshaw et al., 2008; Bosch et al., 2016). In addition, dorsal muscle tissue is considered a representative portion of fish for human consumption (Adams et al., 2003).

Fish ranged in length from $52.32 \mathrm{~cm}(10,1 \mathrm{~kg})$ to $139.5 \mathrm{~cm}$ (186 kg), and methylmercury levels were only weakly associated with size $\left(R^{2}<0.1461\right.$, Pearson's $r<0.3822$, $\left.p<0.0001\right)$ (Fig. $\left.1 A\right)$. For instance, in the case of the NWPO and the SCS, tuna had among the lowest methylmercury levels of all fish despite being among the largest fish caught (Table 1, Fig. 1A). A similar weak relationship has been observed between white muscle mercury concentrations and curved fork length of wild and penned Bluefin tuna (Colman et al., 2015) as well as body mass in yellowfin and bigeye tuna (Ferriss et al., 2011).

Likewise, across all 117 tuna, methylmercury levels showed no correlation with the lipid content $\left(\mathrm{R}^{2}<0.00007\right.$, Pearson's $\mathrm{r}<-0.0084, \mathrm{p}<0.9286$ ) in the muscle tissue (Fig. 1B), consistent with an association of this compound with cellular proteins rather than fat (Amlund et al., 2007). Indeed, the fish with the highest methylmercury concentration of $0.821 \mu \mathrm{g} / \mathrm{g}$ wet weight from the NPO had a low lipid content of less than $0.6 \mathrm{wt} \%$.

In contrast, strong effects were observed when examining the impact of capture location on mean methylmercury levels. Several sites were significantly different from each other $[F=10.89$, $\mathrm{P}=<0.0001$, with $\mathrm{df}=(11,105)]$ (Figs. 2 and 3). Mean methylmercury levels across sites varied by a factor of 8 with the highest mean levels detected in fish from the NPO $(0.51 \pm 0.17 \mu \mathrm{g} / \mathrm{g}$ wet weight $)$ and the lowest in fish from the NWPO $(0.06 \pm 0.02 \mu \mathrm{g} / \mathrm{g}$ wet weight) (Fig. 3, Table 1).

Among individual fish, methylmercury levels differed by a factor of 26 , with the 20 most contaminated fish caught in the NPO, GOM, SEPO, SWPO, NWAO, and SEAO. Among these, a cluster of eight fish were all caught in the NPO, with one fish having the highest methylmercury level of all fish with $0.821 \mu \mathrm{g} / \mathrm{g}$ wet weight (Fig. 4). In contrast, the 20 least contaminated fish were caught in the NEPO, GOM, SWPO, SCS and NWPO. Notably, 10 out of these 20 least polluted fish were all caught in the NWPO, with the lowest methylmercury level of $0.032 \mu \mathrm{g} / \mathrm{g}$ wet weight (Fig. 4).

Dynamic sources of both natural and anthropogenic sources of mercury contribute to the mercury in the environment. Two of the 


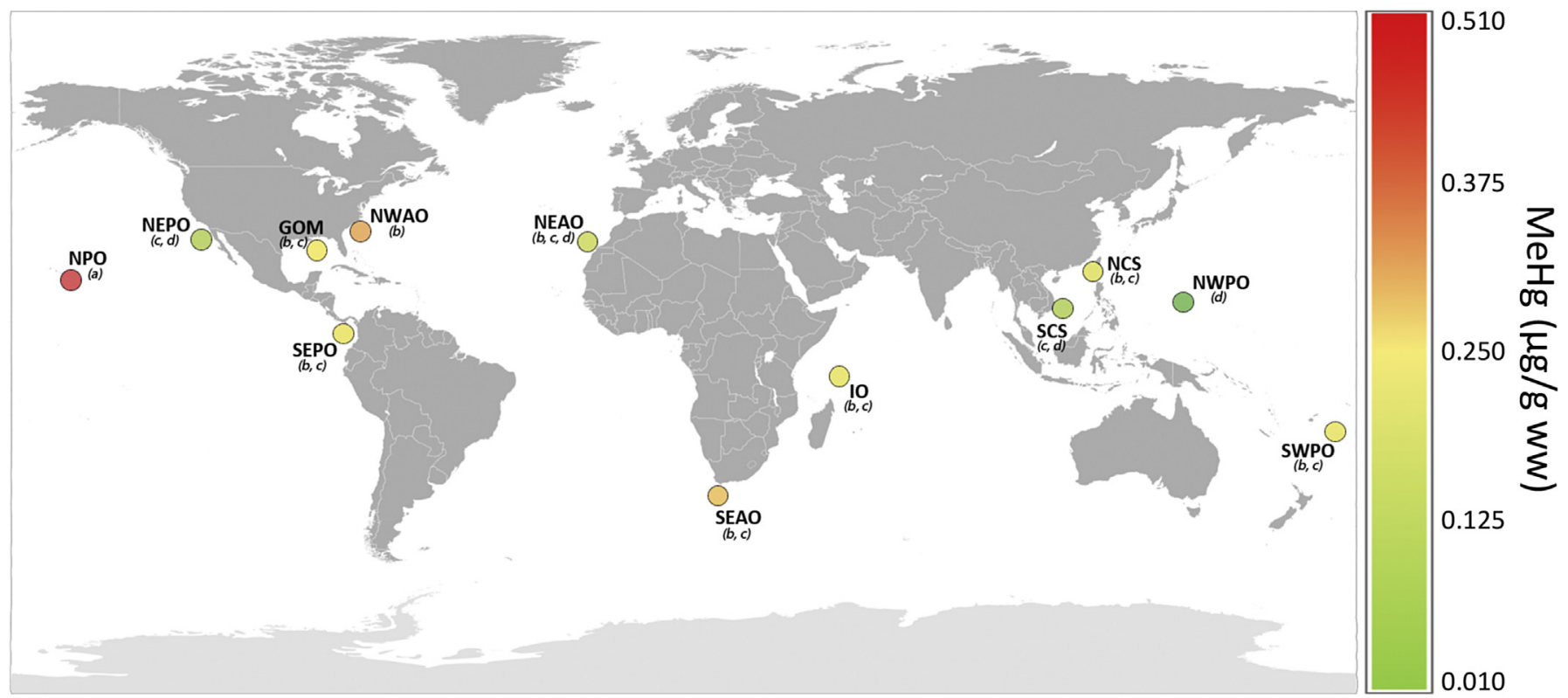

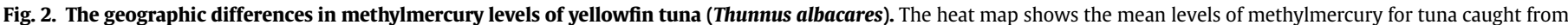
12 different locations ( $\mu \mathrm{g} / \mathrm{g}$ wet weight). Groups with means that were significantly different from each other are indicated with letters $(\alpha=0.05$ ).

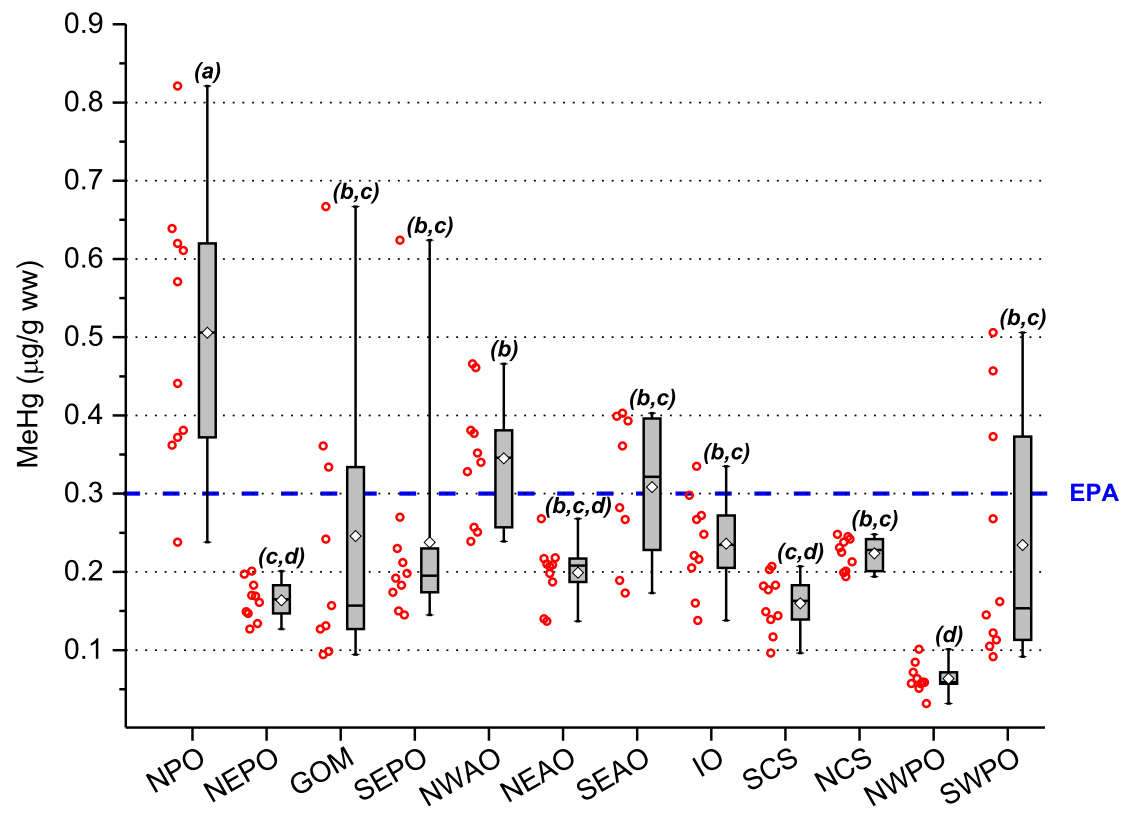

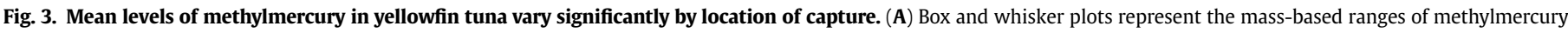

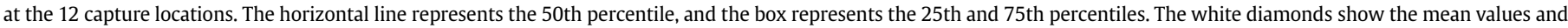

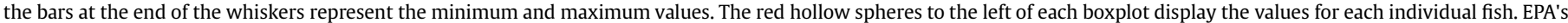

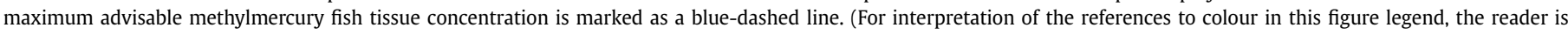
referred to the web version of this article.)

more contaminated sites were relatively distant from human terrestrial inputs, including the NPO and SWPO. However, these sites could be downwind of atmospheric sources of mercury originating in Asia (Strode et al., 2008; Sunderland et al., 2009), and it is estimated that more than half the current global anthropogenic mercury emissions originate from the Asian continent (Pirrone et al., 2010; Selin, 2009; Streets et al., 2009). In addition, given their proximity to volcanic activity there could be additional natural sources of mercury at these locations (Fitzgerald and Lamborg, 2007; Gustin et al., 2008; Pyle and Mather, 2003; Selin, 2009).
As with previous studies we also detected relatively high levels of methylmercury in the fish caught from the GOM and NWAO, suggesting anthropogenic sources of mercury contamination in these fish. Indeed, this might be consistent with mercury contamination via the Atlantic Ocean Loop Current and/or mercury originating in the Mississippi River and being drained into the GOM (Buck et al., 2015; Harris et al., 2012a, 2012b).

An important factor to consider is that ecological variables, in addition to mercury sources, could also play an important role in governing the differences among sites. For instance, although we 


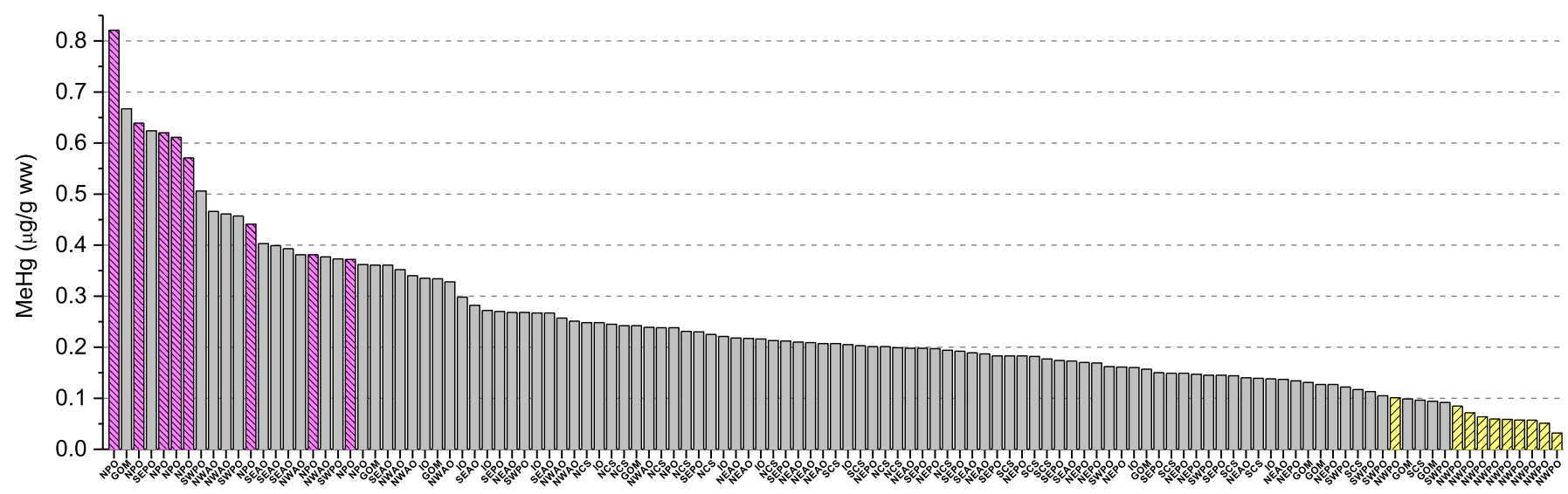

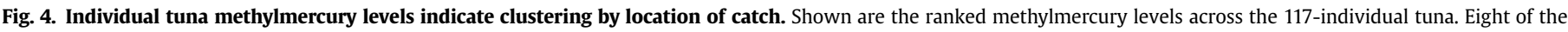

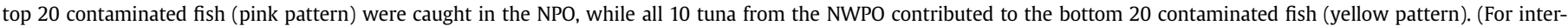
pretation of the references to colour in this figure legend, the reader is referred to the web version of this article.)

looked at a single species, it is well appreciated that differences in population structure among the different sites could influence the actual trophic level of fish (Frank et al., 2005; Layman et al., 2007; Post, 2002). This shift in trophic level could lead to variations in the diet of tuna at different sites. While 1-2-year-old tuna typically feed on smaller fish, crustaceans, squid and gelatinous organisms (Bertrand et al., 2002; Fiedler and Bernard, 1987; Ménard et al., 2006; Olson and Boggs, 1986; Perrin et al., 1973), some recent studies on yellowfin tuna show a more opportunistic feeding behavior, depending on the availability of prey (Rohit et al., 2010; Weng et al., 2016). Notably, the pattern of mercury accumulation in our analyzed yellowfin tuna does not follow the spatial pattern of mercury concentration in the respective thermocline water bodies (Lamborg et al., 2014), indicating that some combination of trophic status, i.e. feeding behavior, and geographic location could be driving the mercury concentrations in these fish.

An implication of our study is that geographic origin of wildcaught fish could be an important factor that governs the potential benefits and risks of fish consumption. It is already well known that there can be significant differences in mercury levels across different fish species, and these differences have been a key element in consumption advisories (USEPA, 2010, 2000). Our study highlights how levels can vary within a single species. In seven locations, the NPO, GOM, SEPO, NWAO, SEAO, IO, and SWPO, the individual fish methylmercury levels often exceeded the EPA's human health criterion (USEPA, 2010) of $0.3 \mu \mathrm{g} / \mathrm{g}$ wet weight (Fig. 3) and overall 24\% (28 fish) were above EPA's methylmercury criterion to protect consumers of fish and shellfish (Figs. 3 and 4). None of the fish had methylmercury levels above current FAO/WHO guidelines and FDA action levels of $1 \mu \mathrm{g} / \mathrm{g}$ wet weight (FDA, 2011; Food and Agriculture Organization (FAO), 2003). However, using this type of geographic information to guide consumption advisories remains a challenge since tracking of fish from capture location to the point of sale is limited (Bailey et al., 2016; Jacquet and Pauly, 2008), particularly for globally distributed species such as yellowfin tuna which are sold in a variety of products, including fresh or frozen steaks and canned.

\section{Conclusions}

This study provides a snapshot of mercury levels in wild yellowfin tuna from around the globe. The results indicate that the geographic origin of catch is a critical factor in determining the mercury levels of fish within species. Thus, human exposure risk to dietary mercury from tuna might be better managed if future guidelines and advisory levels for consumption are informed by the capture location and not just the species and means of production. In such a scenario, mercury exposure might be minimized in vulnerable populations, such as pregnant and nursing women, by providing a means to identify clean sources in the food supply.

\section{Contributions}

S.C.T.N., S.S. and A.H. conceived and designed the study. S.C.T.N. and A.H. analyzed the data and conducted statistical analyses. S.C.T.N. and A.H. wrote the manuscript. L.T.B. collected fish samples.

\section{Conflict of interest}

The authors declare they have no actual or potential competing financial interests.

\section{Acknowledgements}

This work was supported by NIH [grant number ES021985] and NSF [grant number 1314480] to AH and by a Waitt Foundation grant to $\mathrm{AH}$ and $\mathrm{SS}$.

\section{Appendix A. Supplementary data}

Supplementary data related to this article can be found at http:// dx.doi.org/10.1016/j.envpol.2017.05.070.

\section{References}

Adams, D.H., McMichael Jr., R.H., Henderson, G.E., 2003. Mercury levels in marine and estuarine fishes of Florida 1989-2001. revised Wildl. Conserv. 57. http:// dx.doi.org/10.1016/j.neuropharm.2006.03.002.

Amlund, H., Lundebye, A.K., Berntssen, M.H.G., 2007. Accumulation and elimination of methylmercury in Atlantic cod (Gadus morhua L.) following dietary exposure. Aquat. Toxicol. 83, 323-330. http://dx.doi.org/10.1016/ j.aquatox.2007.05.008.

Antunes Dos Santos, A., Appel Hort, M., Culbreth, M., López-Granero, C., Farina, M., Rocha, J.B.T., Aschner, M., 2016. Methylmercury and brain development: a review of recent literature. J. Trace Elem. Med. Biol.1-9. http://dx.doi.org/10.1016/ j.jtemb.2016.03.001.

Bailey, M., Bush, S.R., Miller, A., Kochen, M., 2016. The role of traceability in transforming seafood governance in the global South. Curr. Opin. Environ. Sustain 18, 25-32. http://dx.doi.org/10.1016/j.cosust.2015.06.004.

Balshaw, S., Edwards, J.W., Ross, K.E., Daughtry, B.J., 2008. Mercury distribution in the muscular tissue of farmed southern bluefin tuna (Thunnus maccoyii) is inversely related to the lipid content of tissues. Food Chem. 111, 616-621. http:// dx.doi.org/10.1016/j.foodchem.2008.04.041. 
Bertrand, A., Bard, F.X., Josse, E., 2002. Tuna food habits related to the micronekton distribution in French Polynesia. Mar. Biol. 140, 1023-1037. http://dx.doi.org/ 10.1007/s00227-001-0776-3.

Block, B.A., Jonsen, I.D., Jorgensen, S.J., Winship, A.J., Shaffer, S.A., Bograd, S.J., Hazen, E.L., Foley, D.G., Breed, G.A., Harrison, A.-L., Ganong, J.E., Swithenbank, A., Castleton, M., Dewar, H., Mate, B.R., Shillinger, G.L., Schaefer, K.M., Benson, S.R., Weise, M.J., Henry, R.W., Costa, D.P., Harrison, A.-L., Ganong, J.E., Swithenbank, A., Castleton, M., Dewar, H., Mate, B.R., Shillinger, G.L., Schaefer, K.M., Benson, S.R., Weise, M.J., Henry, R.W., Costa, D.P., 2011. Tracking apex marine predator movements in a dynamic ocean. Nature 475, 86-90. http://dx.doi.org/10.1038/nature10082.

Bosch, A.C., O'Neill, B., Sigge, G.O., Kerwath, S.E., Hoffman, L.C., 2016. Mercury accumulation in Yellowfin tuna (Thunnus albacares) with regards to muscle type, muscle position and fish size. Food Chem. 190, 351-356. http://dx.doi.org/ 10.1016/j.foodchem.2015.05.109.

Bose-O'Reilly, S., McCarty, K., Steckling, N., Lettmeier, B., 2010. Mercury exposure and children's health. Curr. Probl. Pediatr. Adolesc. Health Care 40, 186-215. http://dx.doi.org/10.1016/j.cppeds.2010.07.002.Mercury.

Bošnjak, I., Uhlinger, K.R., Heim, W., Smital, T., Franekić-Čolić, J., Coale, K., Epel, D. Hamdoun, A., 2009. Multidrug efflux transporters limit accumulation of inorganic, but not organic, mercury in sea urchin embryos. Environ. Sci. Technol. 43, 8374-8380. http://dx.doi.org/10.1021/es901677r.

Boush, G.M., Thieleke, J.R., 1983. Total mercury content in yellowfin and bigeye tuna. Bull. Environ. Contam. Toxicol. 30, 291-297. http://dx.doi.org/10.1007/ BF01610135.

Buck, C., Hammerschmidt, C.R., Bowman, K., Gill, G. a., Landing, W.M., 2015. Flux of total and methyl mercury to the northern Gulf of Mexico from U.S. estuaries. Environ. Sci. Technol. http://dx.doi.org/10.1021/acs.est.5b03538 acs.est.5b03538.

Castro-González, M.I., Méndez-Armenta, M., 2008. Heavy metals: implications associated to fish consumption. Environ. Toxicol. Pharmacol. 26, 263-271. http://dx.doi.org/10.1016/j.etap.2008.06.001.

Colman, J.A., Nogueira, J.I., Pancorbo, O.C., Batdorf, C.A., Block, B.A., 2015. Mercury in Pacific bluefin tuna (Thunnus orientalis): bioaccumulation and trans-Pacific Ocean migration. Can. J. Fish. Aquat. Sci. 72, 1015-1023. http://dx.doi.org/ 10.1139/cjfas-2014-0476.

Counter, S.A., Buchanan, L.H., 2004. Mercury exposure in children: a review. Toxicol. Appl. Pharmacol. 198, 209-230. http://dx.doi.org/10.1016/j.taap.2003.11.032.

Cumont, G., Viallex, G., Lelièvre, H., Bobenrieth, P., 1972. Mercury contamination in sea fish. Rev. Int. Ocean. Med. 28, 95-127.

Drevnick, P.E., Lamborg, C.H., Horgan, M.J., 2015. Increase in mercury in Pacific yellowfin tuna. Environ. Toxicol. Chem. 34, 931-934. http://dx.doi.org/10.1002/ etc. 2883.

Driscoll, C.T., Mason, R.P., Chan, H.M., Jacob, D.J., Pirrone, N., 2013. Mercury as a global pollutant: sources, pathways, and effects. Environ. Sci. Technol. 47, 4967-4983. http://dx.doi.org/10.1021/es305071v.

FDA, 2014. Mercury Levels in Commercial Fish and Shellfish (1990-2010), pp. 1-5.

FDA, 2011. Guidance for Industry: Action Levels for Poisonous or Deleterious Substances in Human Food and Animal Feed, 20/04/2011, pp. 1-15.

Ferriss, B.E., Essington, T.E., Kidd, K., 2011. Regional patterns in mercury and selenium concentrations of yellowfin tuna ( Thunnus albacares ) and bigeye tuna ( Thunnus obesus ) in the Pacific Ocean. Can. J. Fish. Aquat. Sci. 68, 2046-2056. http://dx.doi.org/10.1139/f2011-120.

Fiedler, P.C., Bernard, H.J., 1987. Tuna aggregation and feeding near fronts observed in satellite imagery. Cont. Shelf Res. 7, 871-881. http://dx.doi.org/10.1016/02784343(87)90003-3.

Fitzgerald, W.F., Lamborg, C.H., 2007. Geochemistry of mercury in the environment. In: Environmantal Geochemistry: Treatise on Geochemistry on Geochemistry. Elsevier, Oxford, pp. 107-148.

Food and Agriculture Organization (FAO), 2003. Heavy Metals Regulations Legal Notice No. 66/2003.

Frank, K.T., Petrie, B., Choi, J.S., Leggett, W.C., 2005. Trophic cascades in a formerly cod-dominated ecosystem. Sci. (80-. ) 308, 1621-1623. http://dx.doi.org/ 10.1126/science.1113075.

García-Hernández, J., Cadena-Cárdenas, L., Betancourt-Lozano, M., García-De-LaParra, L.M., García-Rico, L., Márquez-Farías, F., 2007. Total mercury content found in edible tissues of top predator fish from the Gulf of California, Mexico. Toxicol. Environ. Chem. 89, 507-522. http://dx.doi.org/10.1080/ 02772240601165594.

Grandjean, P., Satoh, H., Murata, K., Eto, K., 2010. Adverse effects of methylmercury: environmental health research implications. Environ. Health Perspect. 118, 1137-1145. http://dx.doi.org/10.1289/ehp.0901757.

Gustin, M.S., Lindberg, S.E., Weisberg, P.J., 2008. An update on the natural sources and sinks of atmospheric mercury. Appl. Geochem. 23, 482-493. http:// dx.doi.org/10.1016/j.apgeochem.2007.12.010.

Hall, R.A., Zook, E.G., Meaburn, G.M., 1978. National Marine Fisheries Service Survey of Trace Elements in the Fishery Resource. NOAA. Technical Report NMFS SSRF721313.

Harris, R., Pollman, C., Hutchinson, D., Landing, W., Axelrad, D., Morey, S.L., Dukhovskoy, D., Vijayaraghavan, K., 2012a. A screening model analysis of mercury sources, fate and bioaccumulation in the Gulf of Mexico. Environ. Res. 119, 53-63. http://dx.doi.org/10.1016/j.envres.2012.08.013.

Harris, R., Pollman, C., Landing, W., Evans, D., Axelrad, D., Hutchinson, D., Morey, S.L., Rumbold, D., Dukhovskoy, D., Adams, D.H., Vijayaraghavan, K., Holmes, C., Atkinson, R.D., Myers, T., Sunderland, E., 2012b. Mercury in the Gulf of Mexico: sources to receptors. Environ. Res. 119, 42-52. http://dx.doi.org/10.1016/ j.envres.2012.08.001.

Hightower, J.M., Moore, D., 2003. Mercury levels in high-end consumers of fish. Environ. Health Perspect. 111, 604-608. http://dx.doi.org/10.1289/ehp.5837.

ISSF, 2015. ISSF tuna stock status update, 2015: status of the world fisheries for tuna. ISSF Tech. Rep. 03A, 1-96.

Jacquet, J.L., Pauly, D., 2008. Trade secrets: renaming and mislabeling of seafood. Mar. Policy 32, 309-318. http://dx.doi.org/10.1016/j.marpol.2007.06.007.

Kaneko, J.J., Ralston, N.V.C., 2007. Selenium and mercury in pelagic fish in the central North Pacific near Hawaii. Biol. Trace Elem. Res. 119, 242-254. http:/ dx.doi.org/10.1007/s12011-007-8004-8.

Karagas, M., Choi, A., Oken, E., Horvat, M., Schoeny, R., Kamai, E., Cowell, W. Grandjean, P., Korrick, S., 2012. Evidence on the human health effects of lowlevel methylmercury exposure. Environ. Health Perspect. 120, 799-806.

Kikkawa, B.S., Cushing, J.W., 2002. Growth of Yellowfin Tuna (Thunnus albacares) in the Equatorial Western Pacific Ocean, pp. 1-13.

Kojadinovic, J., Potier, M., Le Corre, M., Cosson, R.P., Bustamante, P., 2006. Mercury content in commercial pelagic fish and its risk assessment in the Western Indian Ocean. Sci. Total Environ. 366, 688-700. http://dx.doi.org/10.1016 j.scitotenv.2006.02.006.

Kraepiel, A.M.L., Keller, K., Chin, H.B., Malcolm, E.G., Morel, F.M.M., 2003. Sources and variations of mercury in tuna. Environ. Sci. Technol. 37, 5551-5558. http:// dx.doi.org/10.1021/es0340679.

Lamborg, C.H., Hammerschmidt, C.R., Bowman, K.L., Swarr, G.J., Munson, K.M. Ohnemus, D.C., Lam, P.J., Heimbürger, L.-E., Rijkenberg, M.J. a., Saito, M. a, 2014 A global ocean inventory of anthropogenic mercury based on water column measurements. Nature 512, 65-68. http://dx.doi.org/10.1038/nature13563.

Layman, C.A., Quattrochi, J.P., Peyer, C.M., Allgeier, J.E., 2007. Niche width collapse in a resilient top predator following ecosystem fragmentation. Ecol. Lett. 10 937-944. http://dx.doi.org/10.1111/j.1461-0248.2007.01087.x.

Lowenstein, J.H., Burger, J., Jeitner, C.W., Amato, G., Kolokotronis, S.-O., Gochfeld, M., 2010. DNA barcodes reveal species-specific mercury levels in tuna sushi that pose a health risk to consumers. Biol. Lett. 6, 692-695. http://dx.doi.org 10.1098/rsbl.2010.0156.

Mason, R., Fitzgerald, W., Morel, F., 1994. The biogeochemical cycling of elemental mercury: anthropogenic influences. Geochim. Cosmochim. Acta 58, 3191-3198. http://dx.doi.org/10.1016/0016-7037(94)90046-9.

Mason, R.P., Reinfelder, J.R., Morel, F.M.M., 1996. Uptake, toxicity, and trophic transfer of mercury in a coastal diatom. Environ. Sci. Technol. 30, 1835-1845. http://dx.doi.org/10.1021/es950373d.

Mason, R.P., Reinfelder, J.R., Morel, F.M.M., 1995. Bioaccumulation of mercury and methylmercury. In: Mercury as a Global Pollutant. Springer Netherlands, Dordrecht, pp. 915-921. http://dx.doi.org/10.1007/978-94-011-0153-0_98.

Matthews, A.D., 1983. Mercury content of commercially important fish of the Seychelles, and hair mercury levels of a selected part of the population. Environ. Res. 30, 305-312. http://dx.doi.org/10.1016/0013-9351(83)90216-5.

Ménard, F., Labrune, C., Shin, Y.J., Asine, A.S., Bard, F.X., 2006. Opportunistic predation in tuna: a size-based approach. Mar. Ecol. Prog. Ser. 323, 223-231. http:// dx.doi.org/10.3354/meps323223.

Morel, F.M.M., Kraepiel, A.M.L., Amyot, M., 1998. The chemical cycle and bioaccumulation of mercury. Annu. Rev. Ecol. Syst. 29, 543-566. http://dx.doi.org/ 10.1146/annurev.ecolsys.29.1.543.

Olson, R.J., Boggs, C.H., 1986. Apex predation by yellowfin tuna ( Thunnus albacares ): independent estimates from gastric evacuation and stomach contents, bioenergetics, and cesium concentrations. Can. J. Fish. Aquat. Sci. 43, 1760-1775. http://dx.doi.org/10.1139/f86-220.

Ordiano-Flores, A., Galvn-Magana, F., Rosiles-Martinez, R., 2011. Bioaccumulation of mercury in muscle tissue of yellowfin tuna, Thunnus albacares, of the eastern Pacific Ocean. Biol. Trace Elem. Res. 144, 606-620. http://dx.doi.org/10.1007/ s12011-011-9136-4.

Perrin, W.F., Warner, R.R., Fiscus, C.H., Holts, D.B., 1973. Stomach contents of porpoise, Stenella spp., and yellowfin tuna, Thunnus albacares, in mixed-species aggregations. Fish. Bull. 71, 1077-1092.

Pirrone, N., Cinnirella, S., Feng, X., Finkelman, R.B., Friedli, H.R., Leaner, J., Mason, R., Mukherjee, A.B., Stracher, G.B., Streets, D.G., Telmer, K., 2010. Global mercury emissions to the atmosphere from anthropogenic and natural sources. Atmos. Chem. Phys. 10, 5951-5964. http://dx.doi.org/10.5194/acp-10-5951-2010.

Post, D.M., 2002. The long and short of food-chain length. Trends Ecol. Evol. 17, 269-277. http://dx.doi.org/10.1016/S0169-5347(02)02455-2.

Pyle, D.M., Mather, T.A., 2003. The importance of volcanic emissions for the globa atmospheric mercury cycle. Atmos. Environ. 37, 5115-5124. http://dx.doi.org/ 10.1016/j.atmosenv.2003.07.011.

Rice, K.M., Walker, E.M., Wu, M., Gillette, C., Blough, E.R., 2014. Environmental mercury and its toxic effects. J. Prev. Med. Public Heal 47, 74-83. http:// dx.doi.org/10.3961/jpmph.2014.47.2.74.

Rohit, P., Syda Rao, G., Rammohan, K., 2010. Feeding strategies and diet composition of yellowfin tuna Thunnus albacares (Bonnaterre, 1788) caught along Andhra Pradesh, east coast of India. Indian J. Fish. 57, 13-19.

Scheuhammer, A.M., Meyer, M.W., Sandheinrich, M.B., Murray, M.W., 2007. Effects of environmental methylmercury on the health of wild birds, mammals, and fish. Ambio 36, 12-18. http://dx.doi.org/10.1579/0044-7447(2007)36[12:EOEMOT]2.0.CO;2.

Selin, N.E., 2009. Global biogeochemical cycling of mercury: a review. Annu. Rev. Environ. Resour. 34, 43-63. http://dx.doi.org/10.1146/ annurev.environ.051308.084314. 
Streets, D.G., Zhang, Q., Wu, Y., 2009. Projections of global mercury emissions in 2050. Environ. Sci. Technol. 43, 2983-2988. http://dx.doi.org/10.1021/ es802474j.

Strode, S.A., Jaeglé, L., Jaffe, D.A., Swartzendruber, P.C., Selin, N.E., Holmes, C., Yantosca, R.M., 2008. Trans-Pacific transport of mercury. J. Geophys. Res. Atmos. 113, 1-12. http://dx.doi.org/10.1029/2007JD009428.

Sunderland, E.M., Krabbenhoft, D.P., Moreau, J.W., Strode, S.A., Landing, W.M., 2009 Mercury sources, distribution, and bioavailability in the North Pacific Ocean: insights from data and models. Glob. Biogeochem. Cycles 23, 1-14. http:// dx.doi.org/10.1029/2008GB003425.

Trasande, L., Landrigan, P.J., Schechter, C., 2005. Public health and economic consequences of methyl mercury toxicity to the developing brain. Environ. Health Perspect. 113, 590-596. http://dx.doi.org/10.1289/ehp.7743.

USEPA, 2010. Guidance for Implementing the January 2001 Methylmercury Water Quality Criterion. EPA 823-R-10-001. U.S. Environmental Protection Agency,
Office of Water, Washington, DC, Washington.

USEPA, 2000. Guidance for Assessing Chemical Contaminant Data for Use in Fish Advisories, Volume 2: Risk Assessment and Fish Consumption Limits, third ed. United States Environmental Protection Agency, Washington, DC. EPA 823-B00-008.

Weng, J.-S., Lee, M.-A., Liu, K.-M., Hsu, M.-S., Hung, M.-K., Wu, L.-J., 2016. Feeding ecology of juvenile yellowfin tuna from waters southwest of Taiwan inferred from stomach contents and stable isotope analysis. Mar. Coast. Fish. 7, 537-548. http://dx.doi.org/10.1080/19425120.2015.1094157.

Wiener, J.G., Spry, D.J., 1996. Toxicological significance of mercury in freshwater fish. Environ. Contam. Wildl. 0, 297-339.

Yamashita, Y., Omura, Y., Okazaki, E., 2005. Total mercury and methylmercury levels in commercially important fishes in Japan. Fish. Sci. 71, 1029-1035. http:// dx.doi.org/10.1111/j.1444-2906.2005.01060.x. 